\title{
Uncovering the Research Potential of Administrative Data on Charitable Foundations in Canada
}

\author{
Iryna Khovrenkov \\ University of Regina \\ Lynn Gidluck \\ University of Regina
}

\begin{abstract}
ASTRACT
This is the first study of its kind to assess the untapped research capacity of administrative data on Canadian foundations. More than twenty years of records collected by the Canada Revenue Agency (CRA) for the entire population of foundations is publicly accessible to researchers. Canadian data offers greater opportunity for nuanced analysis of the charitable foundation sector than information from the comparatively small sample available for U.S. foundations. Despite the richness of Canadian data and the potential it has to inform grantmaking and administrative practices of foundations, the academic community has paid little attention to this wealth of statistical information. This article explores some of the questions that this data can potentially answer. Consultations with foundation representatives help illuminate the directions that the foundation sector would like researchers to pursue with this data.
\end{abstract}

\section{RÉSUMÉ}

Ceci est la première étude de son genre à évaluer comment certaines données administratives pourraient contribuer à la recherche sur les fondations caritatives canadiennes. En effet, plus de vingt ans de données accumulées par l'Agence du revenu du Canada pour la population entière des fondations sont maintenant accessibles aux chercheurs. Ces données canadiennes représentent une occasion exceptionnelle pour effectuer une analyse nuancée du secteur des fondations caritatives, occasion qui est meilleure qu'aux États-Unis, où l'échantillon est relativement petit. Malgré la richesse des données canadiennes et leur potentiel d'améliorer l'octroi de bourses et l'administration des fondations canadiennes, la communauté académique a porté peu d'attention jusqu'à présent à cette manne de statistiques. Cet article-ci en revanche explore quelques-unes des questions auxquelles ces données pourraient porter des réponses. En outre, des consultations faites auprès des représentants de certaines fondations aident à signaler les directions que le secteur pourrait prendre grâce à ces données.

KEYWORDS / MOTS CLÉS Administrative data; Research capacity; Community-based approach; Charitable foundations / Données administratives; Capacité de recherche; Approche communautaire; Fondations caritatives 


\section{Khovrenkov \& Gidluck (2017)}

\section{INTRODUCTION}

While Canada's foundation sector may be considerably smaller than its counterparts in the United States and the United Kingdom, it is far from insignificant (Pue \& Breznitz, 2017). In the past twenty years, the Canadian foundation sector solidified its presence, doubling from 5,400 foundations in 1992 to 10,644 foundations in 2016. Over this time period, these entities transferred a total of $\$ 54$ billion as gifts to charities, making them the most significant funders among other private contributors (Imagine Canada \& Philanthropic Foundations Canada, 2014), controlling approximately one out of every six dollars in the charitable sector in Canada (Pue \& Breznitz, 2017).

Government retrenchment and fiscal restraint, which began in the 1990s (and continues to be a prevailing concern), is pushing many nonprofits to try to develop a more diversified revenue base. The scaling back of public financing, together with funding instruments such as contracts and contribution agreements that have constrained flexibility and caused an erosion of core funding, means that accessing funding from sources other than government, such as foundations, is more important than ever (Phillips, Laforest \& Graham, 2010). Foundations also represent an independent source of funding that helps civil society counterbalance the forces of markets and states, with the potential to fund innovative projects that might otherwise not be supported (Anheier \& Leat, 2013).

Developments in the foundation sector have been of great interest to the policy community as evidenced by the fact that every budget document since 2004 introduced a policy either directly or indirectly related to promoting foundation operations. Despite the importance of charitable foundations to the Canadian economy, and the contribution they make to the social fabric of communities across the country, relatively little is known about this sector. Compared to the U.S., which has produced a large scholarly literature, quantitative study of Canadian foundations is paltry. A review of related academic and grey literature uncovered only eight papers, most of which portray broad trends of foundation operations.

The good news is that opportunities for in-depth research are plentiful and have a global advantage. Canada is the only country in the world where more than twenty years of administrative data is available for the entire population of charitable foundations. Moreover, this data, which is collected annually by the Canada Revenue Agency (CRA), is publicly accessible, at no financial cost, to researchers. It offers further opportunity for nuanced analysis because it can be linked to other open data sources, such as information on foundation grantees and their socioeconomic characteristics. These data sources have tremendous potential to assist foundation executives, the academic community, and those working in government and the private sector to draw evidence-based decisions on the grantmaking and administrative practices of foundations.

The aim of this exploratory article is to advance knowledge about the operation of Canadian foundations through the lens of available CRA data. The article has several areas of analysis. It first provides a critical review of existing data issues noted in the quantitative literature on Canadian foundations and then offers a detailed description of the CRA data pertaining to foundations. To help ensure the direction taken with future research is responsive to community needs, the authors consulted with representatives from Philanthropic Foundations Canada (PFC), the Ontario Trillium Foundation (OTF), and 11 grantmaking foundations in Regina (Saskatchewan, Canada). Drawing on the insights gathered during these consultations, an extensive discussion of the opportunities to meet community needs and a vision on how to supplement these needs with existing data is offered. Finally, the strengths and shortcomings of the CRA data on foundations are assessed with a focus on research applicability. It is hoped that that the scholarly community will embrace the challenge to expand on the preliminary findings offered in this article and make use of this valuable but under-utilized dataset. 


\section{ANALYSIS OF DATA ISSUES IN QUANTITATIVE LITERATURE ON CANADIAN FOUNDATIONS}

An extensive search was conducted of both peer-reviewed and grey literature aimed at identifying all empirical research on Canadian foundations. ${ }^{1}$ The search revealed a paucity of literature on Canadian foundations. Only 16 papers were identified, with just half utilizing quantitative data. The remaining works were localized case studies that relied on qualitative data to inform their findings (for summary see Table A.1 in the Appendix). They are not reviewed in this article because, while they are informative in specific situations, they are limited in applicability (Elson, 2016). Such a small number of studies demonstrates that the foundation sector in Canada remains highly unexplored, especially by academic scholars. This literature is also relatively young, with the majority of papers written in the past ten years. Table 1 offers a summary of the content of the eight quantitative articles.

\section{Table 1: Quantitative papers on Canadian foundations}

\begin{tabular}{|l|l|l|c|}
\hline Author & $\begin{array}{l}\text { Data source } \\
\text { (sample years) }\end{array}$ & Type of analysis & $\begin{array}{l}\text { Reference to } \\
\text { data quality }\end{array}$ \\
\hline Sharpe (1994) & $\begin{array}{l}\text { CRA T3010 form } \\
(1991)\end{array}$ & $\begin{array}{l}\text { Descriptive: } \\
\text { trends and patterns }\end{array}$ & Yes \\
\hline Hall \& MacPherson (1995) & $\begin{array}{l}\text { CRA T3010 form } \\
(1993)\end{array}$ & $\begin{array}{l}\text { Descriptive: } \\
\text { trends and patterns }\end{array}$ & No \\
\hline Payne \& Zhao (2007) & $\begin{array}{l}\text { CRA T3010 form } \\
(1992-2004)\end{array}$ & $\begin{array}{l}\text { Descriptive: } \\
\text { trends and patterns }\end{array}$ & Nos \\
\hline Ayer, Hall, \& Vodarek (2009) & $\begin{array}{l}\text { CRA T3010 form } \\
(2003-2007)\end{array}$ & $\begin{array}{l}\text { Descriptive: } \\
\text { trends and patterns }\end{array}$ & Yes \\
\hline Payne (2012) & $\begin{array}{l}\text { CRA T3010 form } \\
(1992-2008)\end{array}$ & $\begin{array}{l}\text { Descriptive: } \\
\text { trends and patterns }\end{array}$ & Yes \\
\hline Kryvoruchko (2013) & $\begin{array}{l}\text { CRA T3010 form } \\
(1997-2008)\end{array}$ & $\begin{array}{l}\text { Empirical analysis: } \\
\text { estimation }\end{array}$ & Yes \\
\hline $\begin{array}{l}\text { Imagine Canada and Philanthropic } \\
\text { Foundations Canada (2014) }\end{array}$ & $\begin{array}{l}\text { CRA T3010 form } \\
(2002-2012)\end{array}$ & $\begin{array}{l}\text { Descriptive: } \\
\text { trends and patterns }\end{array}$ \\
\hline Khovrenkov (2016) & $\begin{array}{l}\text { CRA T3010 form } \\
(1992-2008)\end{array}$ & $\begin{array}{l}\text { Descriptive: } \\
\text { trends and patterns }\end{array}$ & Yes \\
\hline
\end{tabular}

Source: authors' compilations

One of the key findings from this comprehensive search is that researchers choose the data from information returns (an official T3010 form) filed by foundations with the Canada Revenue Agency (CRA) as the primary source for obtaining quantitative information about foundations. These data provide detailed information on a foundation's fundraising activities, financial structure, grant-giving, with a link to the recipients of grants, employment characteristics, and governance structure.

This review of quantitative literature on Canadian foundations also reveals that the analysis offered in the majority of previous works is predominantly descriptive, illustrating in broad strokes the composition of the Canadian foundation sector and an overview of foundation operations. A great, untapped territory for research remains, the findings from which can assist in developing new policies or in reshaping existing ones. Engaging in the analysis of administrative data, however, 


\section{Khovrenkov \& Gidluck (2017)}

requires considerable caution if it is to be used for research purposes. Most of the reviewed studies claim that the CRA data collected from charities' information returns suffers from numerous data quality issues. For example, David Sharpe (1994), Michael Hall and Laura G. MacPherson (1997), Steven Ayer, Michael Hall, and Lindsay Vodarek (2009), and Imagine Canada and Philanthropic Foundations Canada (2014) have identified data issues such as omission errors (e.g., failure to report values leading to an incomplete record or absence of a financial record altogether), addition errors (e.g., components not adding up to reported totals), and discrepancies (e.g., a foundation that claims to have transferred a grant to another charity has no record of the dollar amount disbursed). Ayer et al. (2009) find that discrepancies in the data on fundraising costs are particularly problematic. They conclude that 27 percent of organizations that report having spent on fundraising record zero dollars for fundraising costs. Other reporting errors found by Iryna Khovrenkov (2016, forthcoming) include a negative record of financial measures such as tax-receipted donations, revenues from fundraising, total assets, total expenses, and total government revenues, which are converted to positive. As claimed by Sharpe (1994), the quality of reporting may depend on the size of an organization-larger institutions make fewer errors as they employ reliable financial management staff as opposed to smaller institutions, which are often run by volunteers. Errors are also bound to occur during the conversion of paper copies of the information returns to their electronic records, a procedure that is still performed manually by CRA staff (Payne, 2012).

In addition to overcoming reporting errors, Abigail Payne and Huizi Zhao (2007), Payne (2012), and Khovrenkov (2016, forthcoming) have dealt with other problematic issues of Canadian administrative data on charities. ${ }^{2}$ One example is the CRA's updating of the form "T3010 Registered Charity Information Return," which occurred in 2003 and 2005. The four studies bring awareness to the fact that a change in the T3010 form during the sample period may lead to some financial measures being reported differently. Careful verification needs to be performed to ensure consistency of measures across years. The second example is that organizations may change their registration status with the CRA, where, for instance, a charitable organization is re-designated to a public foundation or vice versa. Payne (2012) and Khovrenkov (2016, forthcoming) have dealt with this issue by grouping charitable organizations and foundations according to their last reported status to avoid potentially double-counting organizations. Finally, the third example is changes in fiscal periods. The four studies account for such changes by ensuring that a record reflects a timeframe of approximately one year (more than 10 months and less than 14 months). This approach allows for consistency across records and improves the overall quality of the dataset.

The three examples noted above are not specific to the data on foundations and apply to all registered charities. In a comprehensive report, François Brouard (2014) reviews all T3010 data issues pertaining to research and also (Brouard, 2015) analyzes reporting issues concerning only foundations. To avoid unnecessary repetition, this article discusses the strengths and limitations of administrative data as they relate specifically to the research on foundations.

As for the data on foundations, Khovrenkov (forthcoming) and Imagine Canada \& Philanthropic Foundations Canada (2014) have utilized data from the Qualified Donee Worksheet (T1236 form) to create a sample of grantmaking foundations. Data from the T1236 form offers information on gift recipients recorded by their unique business numbers and charity names, and specific gift amounts transferred to other registered charities. In its current form, grants data requires considerable cleaning. Two key issues are worth highlighting. The first issue is numerous errors in unique business numbers assigned to each charity. Business numbers (BNs) of charities are assigned by the CRA at registration and must have a standard format with 15 characters: 9 numbers, 2 letters representing a program identifier, and 4 characters reflecting a reference number (e.g., "129669206RR0001") (Canada, 2011).

Current errors include business numbers with more than 15 characters, the absence of program identifiers, and the presence of non-numeric characters. The second issue is a mismatch of the gifts reported having been given by foundations 


\section{Khovrenkov \& Gidluck (2017)}

to those reported as received by charitable organizations. This issue is discovered upon linking gifts data with the data on charitable organizations. Overcoming these problems is essential for creating a rich dataset, and a manual verification and correction of errors are required.

From the analysis of data issues identified in existing quantitative literature on Canadian foundations, it can be concluded that it is important for researchers to devote considerable time to converting administrative data to a research-suitable dataset. Scholars conducting empirical work on the charitable sector would also benefit from a transparent description of exclusions, corrections, and various judgement calls undertaken during the conversion process, which could be included in a technical appendix.

\section{DESCRIBING ADMINISTRATIVE DATA ON CANADIAN FOUNDATIONS}

All charities in Canada must register with the Canada Revenue Agency (CRA) to receive an income tax exemption, issue tax receipts for individual donations, and receive grants from other registered charities. ${ }^{3}$ Upon registration, the CRA classifies all charities into either charitable organizations or foundations and assigns them a unique business number. Charitable organizations are primarily engaged in administering and delivering a range of public goods and services, whereas foundations devote much of their activities to raising funds and allocating them as grants to other registered charities. The CRA also assigns all charities into six broad categories identified by their charitable purposes such as social welfare, community, religion, health, education, and culture. ${ }^{4}$ While there is a large overlap between foundations and charitable organizations in the CRA requirements, this discussion primarily pertains to charitable foundations.

\section{Table 2: Foundation's complete information return}

\begin{tabular}{|l|l|}
\hline Forms & Description \\
\hline $\begin{array}{l}\text { Registered Charity Information } \\
\text { Return }\end{array}$ & $\begin{array}{l}\text { This is the main document filed by foundations and it forms the core dataset for } \\
\text { research purposes. This form collects information about compensation, activities } \\
\text { outside of Canada, fundraising activities, involvement in political activities, categories of } \\
\text { assets, revenues, expenditures, and liabilities. }\end{array}$ \\
\hline $\begin{array}{l}\text { Directors and } \\
\text { Trustees Worksheet } \\
\text { (Form T1235) }\end{array}$ & $\begin{array}{l}\text { This form provides information on individuals associated with the foundation, either } \\
\text { from a governance perspective (board of directors/trustees) or paid staff. Information } \\
\text { includes the length of tenure, what their position is, and whether they are at arms- } \\
\text { length or not with other directors. }\end{array}$ \\
\hline $\begin{array}{l}\text { Qualified Donees Worksheet } \\
\text { (Form T1236) }\end{array}$ & $\begin{array}{l}\text { This form collects information on the specific gift amounts transferred to other } \\
\text { registered charities, and also their gift recipients by unique business numbers and } \\
\text { charity names. }\end{array}$ \\
\hline $\begin{array}{l}\text { Excess Corporate Holdings } \\
\text { Worksheet (Form T2081) }\end{array}$ & $\begin{array}{l}\text { This form is specific to private foundations offering information on the number of } \\
\text { shares, their fair market value, and on the corporate holdings of a foundation. }\end{array}$ \\
\hline
\end{tabular}

Source: Authors' compilations. Canada (2017). Charities Listings. ON: Canada Revenue Agency. URL: http://www.cra-arc.gc.ca/ebci/haip/srch/advancedsearch-eng.action [December 4, 2017]

The CRA mandates that all foundations file an annual return within six months from the end date of their fiscal periods. Failure to comply with these regulations could result in the loss of their charitable status. ${ }^{5}$ Upon filing, foundations are required to indicate their designation as either public or private depending on the relationship between the sources of 


\section{Khovrenkov \& Gidluck (2017)}

funding to the foundation and the number of donors related by family or marriage. A complete return consists of the primary information return (T3010 form) that collects detailed information on fundraising, grant giving, and the financial operations of foundations. Three supporting documents, where applicable, must also be filed. These additional forms incorporate information about the governance structure of foundations (form T1235), the recipients of foundation grants (form T1236), and excess corporate holdings for private foundations (form T2081). Even if filed separately, these forms are tied to a foundation's unique business number, which creates an opportunity to link information from these documents into a comprehensive record. Table 2 provides a short description of each document that forms a foundation's return.

How does collected information about foundations translate into research-suitable data? Given that the CRA tracks the same kind of information about the same foundation at different points in time, researchers can create a longitudinal sample of foundations. The value of the longitudinal sample is the ability to draw comparisons within and between records. With 13,901 foundations currently registered with the CRA and 22 years (1992-2014) for which information about foundations is gathered, a researcher can work with a database of over 176,000 observations. A sample size this large permits a variety of analyses, from descriptive exercises such as identifying trends to more empirically rigorous efforts that include understanding the effects of policy changes on foundation outcomes. Moreover, detailed information from the return's main T3010 form translates into more than 280 variables, only increasing the research capacity of these data. Table 3 summarizes the variable groupings from the T3010 form and lists the key variables associated with each grouping.

\section{Table 3: Key variables from the foundation's return}

\begin{tabular}{|c|c|}
\hline Variable Groupings & Key Variables \\
\hline Identifiers & $\begin{array}{l}\text { Unique business number; foundation type (public/private); foundation name; category code (welfare/ } \\
\text { community/health, etc.); location (postal code/forward sortation area/city/province); fiscal year end }\end{array}$ \\
\hline \multicolumn{2}{|r|}{ Quantitative } \\
\hline Compensation & $\begin{array}{l}\text { Number of part-time and permanent full-time employees; compensation categories for } 10 \text { highest } \\
\text { positions; total spending on compensation }\end{array}$ \\
\hline Financial structure & $\begin{array}{l}\text { Assets (12 components: cash and short-term investment, long-term investments, capital assets, etc.); } \\
\text { revenues (17 components: tax-receipted donations, government revenue [federal, provincial, local], } \\
\text { revenue from fundraising, etc.); expenditures ( } 21 \text { components: spending on occupancy costs and } \\
\text { advertising, spending on political activities, spending on fundraising, etc.); liabilities ( } 5 \text { components: } \\
\text { accounts payable, deferred revenue, etc.) }\end{array}$ \\
\hline Disbursements & Total gifts made to qualified donees; spending on charitable programs \\
\hline \multicolumn{2}{|r|}{ Qualitative } \\
\hline Fundraising & $\begin{array}{l}\text { Fundraising methods (door-to-door solicitation, dinners, lotteries, sales, mail, etc.); payment provided } \\
\text { to external fundraisers (Yes/No) and method of payment (commissions, bonuses, fees, etc.) }\end{array}$ \\
\hline Other & $\begin{array}{l}\text { Receipt of non-cash gifts (Yes/No) and types of non-cash gifts (art, vehicles, property, privately and } \\
\text { publically traded securities, etc.); participation in political activities (Yes/No); financing programs } \\
\text { outside of Canada (Yes/No); distribute gifts to other registered charities (Yes/No) }\end{array}$ \\
\hline
\end{tabular}




\section{Khovrenkov \& Gidluck (2017)}

A unique feature of the CRA data on foundations is that it includes the entire population of foundations in Canada, as opposed to just a sample as is currently the case in the U.S. Moreover, as of 2013, the Charities Directorate of the CRA has begun transcribing charity information returns and making them available online on the government's data portal (open.canada.ca) under an Open Government License (McMurren, Verhulst, \& Young, 2016). As a result, researchers can easily access a wealth of quantitative information to advance their knowledge about foundations in Canada.

\section{RESEARCH VALUE OF ADMINISTRATIVE DATA ON CANADIAN FOUNDATIONS}

\section{Foundations' perspectives on research potential}

Recent literature has highlighted the importance and benefits of forming collaborative relationships between academics and community partners (Caroll-Scott, Toy, Wyn, Zane, \& Wallace, 2012). These benefits pertain to identifying relevant research needs, refining research questions, and building mutually beneficial research capacity. The Social Sciences and Humanities Research Council (SSHRC), one of Canada's most important funding bodies, emphasizes the significance of collaborative research through its Partnership Engagement, Partnership Development, and Partnership Grants. As Amy Caroll-Scott, Peggy Toy, Roberta Wyn, Jazmin Zane, and Steven Wallace (2012) summarize, working with communities only expands our understanding of the pressing issues, and calls on scholars to tackle research questions that are responsive to community needs.

To learn about how foundations would utilize the comprehensive CRA data, we consulted with representatives from Philanthropic Foundations Canada (PFC), ${ }^{6}$ the Ontario Trillium Foundation (OTF), and 11 grantmaking foundations in Regina (Saskatchewan, Canada), which in their unity represent a diverse group of funders in relation to their size, focus of their charitable purposes, and mandates. ${ }^{7}$ In addition to Income Tax Act designations (public vs. private), foundations can be distinguished by the destination of their grants (within or outside of the organization). Those foundations that transfer funds outside of their organizations are known as grantmaking foundations, while those that direct funds to their "in-house" charitable programs are typically defined as operating foundations (Toepler, 1999). This study focuses specifically on grantmaking foundations because as funders of a wide range of charitable projects, we can learn from them about their historic funding patterns and their future goals with their granting programs. Moreover, because of their community involvement through disbursements, we also surmised that grantmaking foundations would be more knowledgeable of the types of research questions that would be beneficial to the broader charitable sector. Since operating foundations do not offer a source of outside funds to other charities, they would not be in the same position to contribute to the knowledge on charity financing.

Through our consultations, we identified three research themes. The first area of interest to the foundation community pertains to measuring the impact of its giving. More specifically, what is the impact of distributed funds and how can it be measured? For many foundations this question stands as a priority because understanding the outreach and influence of their funds can help them structure their grant giving more effectively (Ebrahim \& Rangan, 2014). The biggest challenge for researchers in answering this question is a lack of appropriate data. To quantify the impact generated by a foundation grant, researchers require information on program participants (treatment group) and non-participants (control group) as well as measurable outcomes. For example, for grants focused on education, researchers require a set of results, such as attendance rates, standardized test scores, and high school graduation. This would allow researchers to link these measures to expected lifetime earnings or quality of life (Ebrahim \& Ragan, 2014).

While the CRA foundation data can link the funder to its recipient, the data lacks information on the description of the grant and the outcomes that were achieved. At the moment, suitable data for measuring impact would need to be gathered by researchers through hand-checking individual foundations to identify the types of programs being supported by their 


\section{Khovrenkov \& Gidluck (2017)}

grants and then by conducting extensive surveys to capture necessary indicators. Some larger granting bodies have recognized the potential that digitizing their data can have to explore previously unanswerable research and policy questions and have made this information available to the research community. For instance, the Ontario Trillium Foundation ${ }^{8}$ now makes its complete granting data available online (with information on grant amounts, purpose of the grant, grantee, etc.), a practice that can be a starting point in an exercise to quantify impact. The Vancouver Foundation, which plans to adopt an open licensing policy in 2017, will also share its complete granting data.

The second research theme relates to foundations becoming more active in supporting the provision of public goods and services. As government dollars flowing to education, health, social services, and other priority areas diminish, some foundations have already begun filling financial gaps and more may choose to fill some of this void if they are made aware of the need. The CRA data is well suited to answer questions about which program areas foundations have funded (or are continuing to support), and which areas are potentially more in need of funding. Moreover, the longitudinal nature and lengthy time frame of the CRA data allows researchers to explore the changes in the landscape of foundation funding over time and policies that may have potentially shaped the operation of foundations in Canada.

Finally, a number of foundations, especially larger funders, expressed interest in exploring whether paying their staff a competitive salary results in better foundation operations. Two research questions can be considered for the empirical analysis: the first is assessing how compensation affects total foundation assets; and the second is establishing the effect of compensation on program spending. As indicated in Table 3, CRA data collects information on total compensation by foundations, for both full-time and part-time positions. It also provides a separate measure on part-time compensation, allowing researchers to determine compensation only for full-time positions. This type of analysis could directly inform the practice of foundations and potentially demonstrate where foundations stand in terms of their role in contributing to expanding the Canadian labour market. Moreover, as the CRA tracks the same information on all registered foundations, it may be a useful benchmarking exercise to draw comparisons across compensation levels for similar foundations.

\section{Moving research forward}

With governments shifting their funding away from traditional long-term granting to short-term project-oriented contracting (Phillips, Laforest, \& Graham, 2010), many charities have found themselves in a state of financial instability, with serious concerns about the future sustainability of their programs and their ability to meet the growing social need for the services they provide (Emmett, 2016). Given these challenging circumstances, the ability to access foundation funding is more important than ever. Solid Canadian data can serve as a useful tool for not only understanding the current funding patterns of the foundation sector but also for guiding charity managers to specific foundations that align with their needs.

The topic of charity financing, while critical, is poorly researched in Canada. An attractive feature of the CRA data compared to U.S. administrative data is that it classifies giving to registered charities into three separate categories: donations from individuals, institutional grants (i.e., funds from foundations or charitable organizations), and government funding. In the U.S., donations from individuals and institutional donors are aggregated into one category, "direct public support" (Heutel, 2014). The advantage of having a disaggregated "giving" category is that it allows researchers to track grants transferred from particular foundations to their unique recipients and provide a detailed characterization of funder-fundee relationships. Khovrenkov's (forthcoming) research, which establishes the link between foundation grants and the ability to attract additional private donations, demonstrates the utility of this data. On this topic alone, there is much more that can be explored.

The comprehensive CRA data on foundations does more than just afford researchers the opportunity to answer novel questions about the Canadian foundation sector. This rich dataset is able to contribute to the scholarship beyond national borders. For example, on the topic of charity financing, Rikki Abzug, Alexandre Olbrecht, Murray Sabrin, and Erwin 


\section{Khovrenkov \& Gidluck (2017)}

DeLeon (2016) explore variation in funding by New Jersey educational foundations to local public schools. Their main challenge in finding the financial impact of foundations on this type of public service is primarily due to a small sample size. The richness and longevity of Canadian foundation data can provide interesting insights into "this curious case of private financing of public services" (p. 134).

Canadian data can shed important light on how charity financing is affected by government regulations. In both Canada and the United States, foundations are required to transfer a portion of their assets (3.5\% in Canada and $5 \%$ in the U.S.) as grants to other registered charities on an annual basis. While regulating foundation disbursements "ensures that foregone tax revenues will be put to public uses" (Toepler, 2004, p. 736), questions have been posed in the U.S. about the overall costs and benefits of this policy approach and whether this type of disbursement regime should be changed (Clotfelter, 1985; Toepler, 2004). Tight disbursement rules are found to have a negative impact on the growth and preservation of assets, which can in turn limit the ability of foundations to provide a sustainable flow of funds for the delivery of charitable programs (Canada, 2004). In a hypothetical analysis, Stefan Toepler (2004) applies Germany's minimal-payout requirement (two-thirds of net income) to Ford Foundation data and compares the results to the actual payouts. In 2004, small Canadian foundations (those with assets less than $\$ 25,000$ ) became fully exempt from asset disbursement requirements altogether. This reform provides researchers with a natural rather than a hypothetical setting to compare changes in grant giving and assets before and after this regulatory amendment. And Canada's comprehensive database on foundations can be employed to establish the differences in these measures for foundations affected by the reform.

There is much more to be learned from this data than just issues related to charity financing and the regulatory framework. Canadian foundation data offers significant opportunities to pursue other topic areas, including the heterogeneity of the foundation sector, the governance structure of foundations, and how changes to the composition of boards can influence foundations' granting patterns. Much can also be learned about whether the political activity of foundations affects funding directions and contributes to a broader dialogue on important questions of public policy.

The operational aspects of foundations (e.g., how funds are distributed, types of charities they support, how foundations are governed, etc.), is an area holding tremendous research potential. Much is known about the differences in the operation of public and private foundations (Income Tax Act designations), their distribution by size and regulatory treatment. This knowledge forms an essential base. However, further exploration of the range of foundations that fall outside of their Income Tax Act definitions would allow for the development of policies that are relevant to the operational needs of the foundation sector. This knowledge would also help foundations to clarify their own practices. With CRA foundations, data researchers can create a detailed profile of a foundation's classifications. For example, building on the work by Jenny Harrow, Tobias Jung, and Susan Phillips (2016) and Siobhan Daly (2008), who provide a strong theoretical basis around the adaptation of the community foundation form in Canada and the U.K., and on the research by Elizabeth Graddy and Lili Wang (2009), who explore the model that connects community social capital and gifts to community foundations in the U.S., we can develop a strong profile of Canadian community foundations and the role their giving plays in our communities. Another example relates to exploring differences between operating and grantmaking foundations. Preliminary analysis of the CRA data reveals that the growth of operating foundations has outpaced the growth of grantmaking foundations since late 2000s. Looking into a possible structural change of the foundation sector has important implications for charity managers who rely on foundations grants to fund their operations.

Francie Ostrower (2007) claims that a foundation's effectiveness is closely related to the strength of its governance structure. Bradley Minaker (2017) used CRA data on religious charities (in conjunction with other data sources) to study the attributes of effective managers of a charitable organization rather than a foundation and how a manager can influence charity finances. He found that an increase in the quality of the charity manager led to an increase in private donations, 


\section{Khovrenkov \& Gidluck (2017)}

government revenues, and donations from other registered charities. Since the CRA data on foundations can be linked to the Trustees and Directors Worksheet (T1235 form), researchers can trace the governance structure of foundations and begin to draw inferences about the decision-making process around foundation grants, which currently remains a black box.

The remaining area of research that lacks any comprehensive data-based evidence (but has recently made a few media headlines), is the engagement of foundations and other registered charities in advocacy. Studying 13 policy-focused grantmaking foundations, Peter Elson and Sara Hall (2016) begin to uncover foundations' appetite for and their role in public policy. All foundations within their sample were focused on the policy issues over the long-term, but adjusted their strategies whenever new information became available. How would these findings translate to all grantmaking foundations? What are the characteristics of foundations that engage in political activities? Does spending on political activities occur at the expense of spending on charitable programs? With available data and recent regulatory changes related to advocacy, uncovering these questions is not only important but also timely.

\section{ASSESSING STRENGTHS AND WEAKNESSES OF THE CRA DATA ON FOUNDATIONS}

\section{Administrative Data vs. Survey Data}

Researchers have argued that administrative data are generally preferable to traditional survey data because the former offer larger sample sizes and fewer technical issues (Card, Chetty, Feldstein, \& Saez, 2011; Hotz, Goerge, Balzekas, \& Margolin, 1997). The CRA data on foundations currently spans a period of twenty-two years (from 1992 to 2014). Researchers can also obtain information on every single foundation registered in Canada for free (Noveck \& Goroff, 2013) as opposed to only a sample on U.S. foundations that file their returns with the Internal Revenue Service (IRS) (a U.S. analogue of the CRA). This lengthy time frame and the size of the dataset are an advantage over survey data because information gathering occurs as a byproduct of the CRA's reporting requirements. In terms of quality, CRA data on foundations has been noted to be adequately accurate, which is an important characteristic when producing policyrelevant research (Imagine Canada \& Philanthropic Foundations Canada, 2014; Payne, 2012).

Collecting longitudinal information via surveys is time-consuming and costly. Another issue with survey data gathering is that not all foundations may respond to questionnaires, resulting in an incomplete dataset, whereas the CRA sample includes all registered foundations. An obvious benefit, however, of conducting a longitudinal survey is that it could acquire information on foundations not collected by the CRA and could also be expanded to include grantmaking bodies that are not registered with the CRA. And if linking administrative data with survey data could be arranged, a practice strongly supported by Joseph Hotz, Robert George, Julie Balzekas, and Francis Margolin (1997), such a type of comprehensive data would allow researchers to describe the funding dynamics of all grantmakers in Canada.

\section{Canadian Foundation Data vs. Other Country Foundation Data}

It is rare for researchers interested in charitable foundations to have access to a database of information as comprehensive as that collected by the Canada Revenue Agency. Researchers from countries such as the United Kingdom, Australia, and New Zealand, for instance, have to piece together data from numerous different sources, where information is collected at different time points and through divergent methodologies (see Leat,2016, for views on foundation data for Australia and New Zealand). The task of putting together a coherent fabric is monumental and even with great care and effort, left with holes and patches. For example, Cathy Pharoah, Richard Jenkins, Keiran Goddard, and Catherine Walker (2016) had to pull together data on the U.K. foundation sector drawn laboriously from financial figures in annual reports, foundations' websites, searches of literature (including press reports), tax statistics, estates data, general public and "high net worth" surveys, and other research. Lack of a legal definition of "foundation" in the U.K. contributes to the chal- 


\section{Khovrenkov \& Gidluck (2017)}

lenge of creating a comprehensive dataset. From a research perspective, the absence of uniform foundation data across countries prohibits a comparative cross-country study of foundations.

While data collected by tax agencies in Australia, New Zealand, and the U.K. is nowhere near as comprehensive as that collected by the CRA in Canada or the IRS in the U.S., its one advantage is that charities in these countries have long been filing their forms electronically. Foundations and charitable organizations in Canada continue to file their information returns by either faxing their forms or mailing them. Upon receipt of a physical return, CRA staff enter the information manually in order to create a digital record of a physical copy. This process of data transfer creates considerable room for error. By late 2018, however, a move to online reporting is expected for all Canadian registered charities. The advent of electronically submitted T3010 forms will offer evident benefits to researchers and field practitioners. In particular, electronic filing will dramatically improve the accuracy, completeness, timeliness, and overall quality of the data (Polak \& Lamkin, 2001).

\section{Other strengths}

The analytic value of the data increases if it can be linked across other datasets. With the level of detail available within the CRA data on foundations, the exercise of integrating information can be easily performed. The Qualified Donee Worksheet (form T1236), which the CRA requires all grantmaking foundations to file as part of their return, collects information on the specific gift amounts transferred to other registered charities and also their gift recipients by unique business numbers and charity names. While in the past the CRA provided information only on the first 10 charity recipients that foundations identified on their Qualified Donee Worksheets, as of 2013, data includes all recipients recorded by foundations. The CRA has also begun to update this information for earlier years (McMurren et al., 2016). This upgrade in the data, distinct to Canada only, creates a unique research opportunity, where scholars can closely examine changes in foundation funding to individual charity-donees and paint a more accurate landscape of charity financing in Canada.

Using unique business numbers of grant recipients, it is possible to match information about these recipients with their funders. Since postal codes are provided for each organization (funder and fundee), CRA data can be linked with other data sources, such as the Census and Elections Canada, for the purposes of establishing causal connections between foundation grants and their impact on charity operations. Approaches to gift collection and the carrying out of charitable activities by charities vary across the neighbourhoods in which these charities operate. That is why it is important to capture socioeconomic and political differences across the relevant neighborhoods.

\section{Data limitations}

Utilizing administrative data on Canadian foundations necessitates the recognition of the limitations of these data and how such shortcomings play into a researcher's analysis. Given that foundations' information returns are filed manually, CRA staff key in the returns in order to create an electronic version of them. The process of data conversion can lead to numerous data errors, which have previously been discussed, but all of which can have additional ramifications if they are not resolved. Two other data-related shortcomings result from changes that may occur within a foundation (e.g., changes in internal accounting processes) and the CRA itself (e.g., updates to information returns leading to questions being framed differently). ${ }^{9}$ Resolving these shortcomings requires thorough hand checking and verification of the data, which may be taxing on a researcher, yet essential for producing quality analyses. For the above reasons, Michael Lenczner and Susan Philips (2012) conclude that the user-friendliness of the data can still be greatly improved.

\section{CONCLUSION}

The goal of this article is to assess the research potential of publically accessible data on charitable foundations in Canada. No other jurisdiction has gone as far as Canada in making data on foundations (and the larger charitable sector) 


\section{Khovrenkov \& Gidluck (2017)}

available to researchers. It is hoped that this initial foray will lay the groundwork for future studies on Canada's charitable foundation sector as much research remains to be undertaken and many interesting avenues exist to create a solid databased understanding of this sector. It is important to ensure that policies and the development of new programs related to the sector originate from evidence-based research (Boothe, 2013).

The CRA's vast data set, in conjunction with the open data movement, has created more opportunities than ever before to address information deficits. Consultations showed that there is an appetite from the sector to collaborate with researchers to pursue avenues that provide robust intelligence to help them in their decision-making. As governments continue to face budgetary cuts, resources available from charitable foundations are becoming of increased importance to policymakers as they pursue innovative ways to partner with communities to support the provision of public goods and services. It is hoped that this article sparks the beginning of a new generation of scholarship about foundations and a broader charitable sector in Canada.

\section{ACKNOWLEDGEMENTS}

The authors gratefully acknowledge the support of the Social Sciences and Humanities Research Council of Canada (SSHRC) Partnership Development Grant. The authors have benefited from comments by members of their research cluster, presentation participants at the International Society for Third Sector Research Conference (ISTR, 2016), and feedback from anonymous reviewers for ANSERJ.

\section{NOTES}

1. Grey literature was defined as documents outside formal academic channels of publication, which included community-based research reports, discussion papers, government documents, as well as information guides and unpublished sources (Magalhaes, Carrasco, \& Gastaldo, 2010).

2. Payne \& Zhao (2007), Payne (2012), and Khovrenkov (2016, forthcoming) rely on CRA data on charitable organizations and foundations that was accessed through Public Economics Data Laboratory Analysis (PEDAL) located at McMaster University, Hamilton, Ontario. PEDAL is "a medium security facility that specializes in transforming and analyzing administrative data" (McMaster University, 2017) for various purposes including research. Dr. Abigail Payne (2012), the director of PEDAL, has devoted considerable effort to developing methods that "help make it feasible to use the information return as a more reliable source for research analysis (p. 7).

3. Registered charities constitute about 50 percent of the broader nonprofit sector. The key difference between registered charities and nonprofit and voluntary organizations is that the former can issue tax receipts for their donations.

4. The CRA internally generates 50 categories for classifying charities according to their stated purposes. Please see Sharpe (1994) for a detailed discussion of category codes.

5. Foundations in Ontario must also file a provincial annual return (RC 232).

6. Philanthropic Foundations Canada is a member association of over 130 Canadian grantmakers. It promotes the growth and development of effective and responsible foundations. The Ontario Trillium Foundation is the agency of the Government of Ontario and one of Canada's largest grantmaking foundations.

7. At the start of the study, Regina was home to only 22 grantmaking foundations, 11 of which responded to our call for consultations, which creates a response rate of 50 percent.

8. The Ontario Trillium Foundation is different from a typical charitable foundation (e.g., Vancouver Foundation) in that it is funded entirely by government as opposed to individual endowments.

9. Registered charities were required to complete form T3010 prior to 2002, then form T3010A between 2003 and 2004 , and form T3010 (05) from 2005 onward. 


\section{Khovrenkov \& Gidluck (2017)}

\section{REFERENCES}

Abzug, R., Olbrecht, A., Sabrin, M., \& DeLeon, E. (2016). Nonprofit financing to the rescue? The slightly twisted case of local educational foundations and public education in New Jersey. Nonprofit and Voluntary Sector Quarterly, 45(1), 133-149.

Anheier, H.K., \& Leat, D. (2013). Philanthropic foundations: What rationales? Social research, 80(2), 449-472.

Ayer, S., Hall, M., \& Vodarek, L. (2009). Perspectives on fundraising: What charities report to the Canada Revenue Agency. Toronto, ON: Imagine Canada.

Boothe, P. (2013). Making good regulation. Canadian Public Policy, 39(3), 359-370.

Brouard, F. (2014). T3010 challenges for research [Discussion paper]. Ottawa, ON: Sprott Center for Social Enterprises, Carleton University.

Brouard, F. (2015). Emerging information and reporting issues for grantmaking foundations [Discussion paper]. Ottawa, ON: Sprott Center for Social Enterprises, Carleton University.

Canada. (2017). 2013 Charities Listings. Ottawa: ON: Canada Revenue Agency. URL: http://open.canada.ca /data/en/dataset/48fa4b32-c92b-4912-b451-c37e590a716a [December 4, 2017].

Canada. (2004). Federal budget plan 2004: New agenda for achievement. Ottawa, ON: Department of Finance.

Canada. (2011). Registration number. Ottawa, ON: Government of Canada. URL: https://www.canada.ca/en/revenueagency/services/charities-giving/charities/operating-a-registered-charity/registration-number.html [September 21, 2017].

Card, D., Chetty, R., Feldstein, M., \& Saez, E. (2011). Expanding access to administrative data for research in the United States. American Economic Association Meetings in Denver, session on "Grand Challenges for Social Science Research: The Perspectives of Economists."

Caroll-Scott, A., Toy, P., Wyn, R., Zane, J.I., \& Wallace, S. (2012). Results from the data and democracy initiative to enhance community-based organization data and research capacity. American Journal of Public Health, 102(7), 1384-1391.

Clotfelter, C. (1985). Foundations. In C. Clotfelter (Ed.), Federal tax policy and charitable giving (pp. 253-272). Chicago, IL: The University of Chicago Press.

Daly, S. (2008). Institutional innovation in philanthropy: Community foundations in the UK. VOLUNTAS: International Journal of Nonprofit and Voluntary Organizations, 19(3), 219-241.

Ebrahim, A., \& Rangan, K. (2014). What impact? The framework for measuring the scale and scope of social performance. University of California Berkley, 56(3), 118-141.

Elson, P. (Ed.). (2016). Funding policies and the non-profit sector in Western Canada. Toronto, ON: Toronto University Press.

Elson, P., \& Hall, S. (2016). System change agents: A profile of policy-fosuced grantmaking foundation engagement in public policy. Canadian Journal of Nonprofit and Social Economy Research, 7(2), 57-78.

Emmett, B. (2016). Charities, sustainable funding and smart growth. Toronto, ON: Imagine Canada.

Graddy, E., \& Wang, L. (2009) Community foundation development and social capital. Nonprofit and Voluntary Sector Quarterly, 38(3), 392-412.

Hall, M., \& MacPherson, L.G. (1997). A provincial portrait of Canada's charities. Canadian Centre for Philanthropy Research Bulletin, 4(2\&3), 12.

Harrow, J., Jung, T., \& Phillips, S.D. (2016) Community foundations: Agility in the duality of foundation and community. In T. Jung, S.D. Phillips, \& J. Harrow (Eds.), The Routledge companion to philanthropy (pp. 308-321). London, UK: Routledge.

Hotz, J., Goerge, R., Balzekas, J., \& Margolin, F. (1997). Administrative data for policy-relevant research: Assessment of current utility and recommendations for development. Chicago, LL: Northwestern University and University of Chicago, Joint Center for Poverty Research. 


\section{Khovrenkov \& Gidluck (2017)}

Heutel, G. (2014). Crowding out and crowding in of private dontations and government grants. Public Finance Review, 42(2), 143-175.

Imagine Canada \& Philanthropic Foundations Canada. (2014). Assets and giving trends of Canada's grantmaking foundations.

Khovrenkov, I. (2016). Size-based analysis of charitable foundations: New evidence from Canadian data. Canadian Public Policy, 42(3), 337-349.

Khovrenkov, I. (forthcoming). Does foundation giving stimulate or suppress private giving? Evidence from a panel of Canadian charities. Public Finance Review.

Leat, D. (2016). From charity to change, Brussels to Beijing. In D. Leat (Ed.), Philanthropic foundations, public good and public policy (pp. 35-52). London, UK: Palgrave Macmillan.

Lenczner, M., \& Phillips, S. (2012, July). From stories to evidence: How mining data can promote innovation in the non-profit sector. Technology Innovation Management Review, 10-15.

Magalhaes, L., Carrasco, C., \& Gastaldo, D. (2010). Undocumented migrants in Canada: A scope literature review on health, access to services, and working conditions. Journal of Immigrant and Minority Health / Center for Minority Public Health, 12(1), 132-151.

Minaker, B. (2017). Three essays in public economics: Charities and charitable giving [PhD dissertation, chapter 2]. Hamilton, ON: McMaster University.

McMaster University. (2017). Public economics data analysis laboratory. URL: https://pedal.mcmaster.ca [December 4, 2017].

McMurren, J., Verhulst, S., \& Young, A. (2016). Opening Canada's T3010 charity information return data. Govlab.

Noveck, B.S., \& Goroff, D. (2013). Information for impact: Liberating nonprofit sector data. Washington, DC: Aspen Institute: Philanthropy \& Social Innovation.

Ostrower, F. (2007). The relativity of foundation effectiveness: The case of community foundations. Nonprofit and Voluntary Sector Quarterly, 36(3), 521-527.

Pharoah, C., Jenkins, R., Goddard, K., \& Walker, C. (2016). Giving trends: Top 300 foundation grant-makers. Association of Charitable Foundations. London, UK: Association of Charitable Foundations.

Polak, T., \& Lamkin, L. (2001). Nonprofit accountability and the National Center for Charitable Statistics. New Directions for Philanthropic Fundraising, 31(2001), 81-102.

Payne, A. (2012). Changing landscapes for charities in canada: Where should we go? School of Public Policy Research Papers, 5(34). Calgary, AB: University of Calgary.

Payne, A., \& Zhao, H. (2007, January 9). Uncharitable treatment: Why donations to private and public foundations deserve equal tax status. Toronto, ON: C.D. Howe Institute e-brief.

Phillips, S.D., Laforest, R., \& Graham, A. (2010). From shopping to social innovation: Getting public financing right in Canada. Policy and Society, 29(3), 189-199.

Pue, K., \& Breznitz, D. (2017) The social innovation strategies of Canadian foundations. Innovation Policy Lab White Paper. Toronto, ON: Munk School of Global Affairs.

Sharpe, D. (1994). A portrait of Canada's charities: The size, scope and financing of registered charities. Toronto, ON: Canadian Centre for Philanthropy.

Statistics Canada. (2009). Satellite account of nonprofit institutions and volunteering: 2007. Ottawa, ON: Statistics Canada. Catalogue no. 13-015-X ISSN: 1710-9264.

Toepler, S. (1999). Operating in grantmaking world: Reassessing the role of operating foundations. In H. Anheier \& S. Toepler (Eds.), Private funds, public purpose: Philanthropic foundations in international perspective. New York, NY: Kluwer Academic/Plenum Publishers.

Toepler, S. (2004). Ending payout as we know it: A conceptual and comparative perspective on the payout requirement by foundations. Nonprofit and Voluntary Sector Quarterly, 33(4), 729-738. 


\section{ABOUT THE AUTHORS / LES AUTEURS}

Iryna Khovrenkov is an economist with research interests in economics of charities, applied microeconomics, public economics and tax policy. Her primary research explores the role of foundations in the Canadian charitable sector including foundation giving and government policies that shape foundation operations. She is Assistant Professor in the Johnson Shoyama Graduate School of Public Policy at the University of Regina. Email: iryna.khovrenkov@uregina.ca .

Lynn Gidluck is coordinator of the Community Research Unit at the University of Regina and is also partner in Benchmark Public Relations, a Regina-based strategic communications and marketing firm. She has an interdisciplinary PhD from the Johnson Shoyama Graduate School of Public Policy at the University of Regina. Email: Iynn.gidluck@uregina.ca . 


\section{Khovrenkov \& Gidluck (2017)}

\section{Appendix: Overview of specific case studies and surveys on foundations}

\begin{tabular}{|c|c|}
\hline Author & Data source \\
\hline Young (2015) & Case study of the Bealight Foundation and its approach to mission related investing. \\
\hline $\begin{array}{l}\text { Hall, de Wit, Lasby, Mclver, } \\
\text { Evers, Terry, Johnston, \& } \\
\text { McAuley (2005) }\end{array}$ & Survey of 13,000 incorporate nonprofits and registered charities. \\
\hline Lasby (2013) & $\begin{array}{l}\text { Imagine Canada's online survey of 2,255 executive directors or other senior leaders of } \\
\text { registered charities. }\end{array}$ \\
\hline Nixon (2013) & $\begin{array}{l}\text { Online survey of representatives from } 66 \text { private, community, and corporate foundations in } \\
\text { Canada and in-depth interviews with } 15 \text { foundation representatives and other leaders in the } \\
\text { field. }\end{array}$ \\
\hline $\begin{array}{l}\text { Northcott \& Uytterhagan } \\
(2002)\end{array}$ & Interviews with 14 representatives from private Canadian foundations. \\
\hline Plant (2003) & Semi-directed interviews with 14 Québec-based and 3 Ontario-based foundation executives. \\
\hline Strandberg (2010) & $\begin{array}{l}\text { Case studies on community and mission investing activities of nine Canadian foundations, } \\
\text { and an overall analysis of the current status of community and mission investing in Canada } \\
\text { based upon the nine profiles. }\end{array}$ \\
\hline Strandberg (2008) & $\begin{array}{l}\text { Case studies of community investment strategies of VanCity Community Foundation and the } \\
\text { Atkinson Foundation. }\end{array}$ \\
\hline Whitman (2006) & $\begin{array}{l}\text { Survey of foundation CEOs: } 5 \text { Canadian foundations; } 45 \text { U.S. foundations, and } 12 \text { European } \\
\text { foundations. }\end{array}$ \\
\hline
\end{tabular}

Source: Authors' compilations 